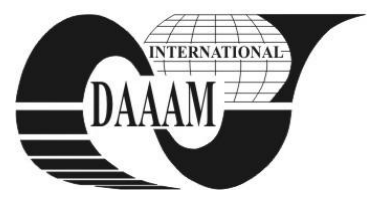

\title{
FUTURE BUSINESS STRATEGIES OF INDEPENDENT BREWERS IN GLOBALIZED WORLD
}

\author{
SOUCKOVA, R[adka]
}

\begin{abstract}
This article aims to identify the areas of growth of independent brewers in the globalized beer business. The beginning of the work describes the global beer business and defines key global beer corporations. The second part identifies the trends in developed and emerging markets. The final fact parts specify business strategies of corporations and define their weaknesses. The last part focuses on positive trend of local, independent brewers on example of craft brewers in USA. In the conclusion, there are some ideas of business strategies.

Key words: beer market, business strategies, globalization
\end{abstract}

\section{INTRODUCTION}

The long-term decline of small and medium size brewers share in domestic beer businesses indicated in a trend of continuous production and trade globalization. Since the 1960s the global beer market has faced gradual elimination of traditional, local brewers who lacked investment forces needed for modernisation or restructuring of production capacities in order to comply with the market requirements and who suffered from insufficient marketing sources for promotion and advertising.

The world has been witnessing merges of companies with local distribution chains and sales of local production facilities to the global beer and investments corporations. These giants come to the markets with the aim of gaining from the awareness and a tradition of existing domestic breweries, and getting the incremental sales and profit out of their purchase. Alternatively, they are motivated by strictly economical reasons helping to save logistics costs, to avoid import duties, or to use existing production facilities for their licence brews of their own global brands. In both cases, we can talk about globalization where the independent brewers must find a way to succeed.

\section{TRENDS}

Currently the global beer business is dominated by leading players, e. g. ABInbev, SABMiller, Heineken, Carlsberg and variety of Asian/Pacific breweries.

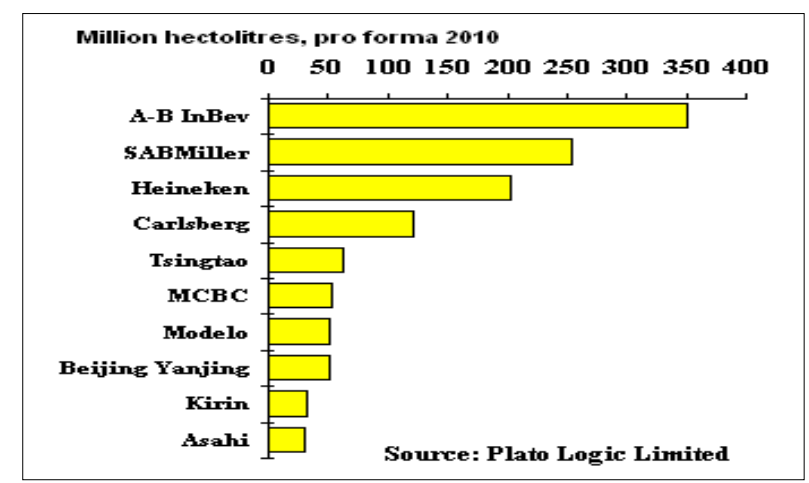

Graph 1. Volumes of TOP 10 brewers (last estimate 2010)
From the geographical perspective, there has been a trend of consumption stagnation on the "developed markets" in the last couple of years. For example in Western Europe, one of key regions for beer production, the decline has represented approximately $8 \%$ since 2004 .

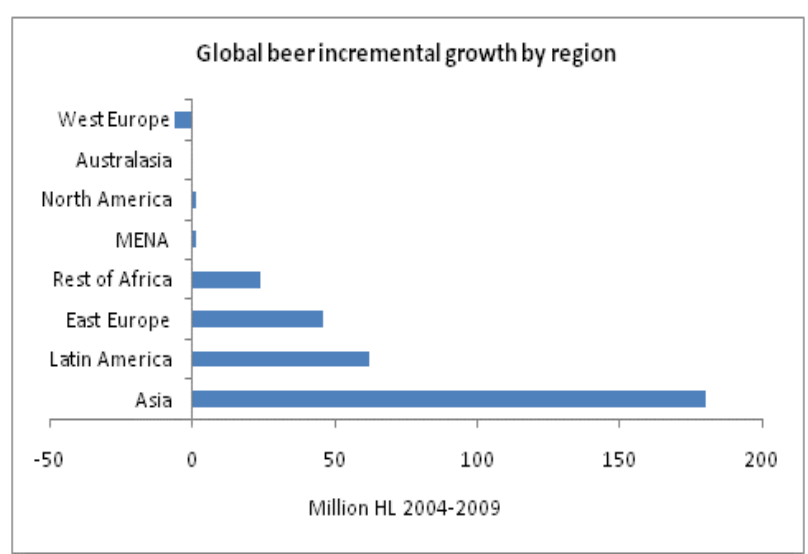

Graph 2. Global beer incremental growth by region,

Therefore, brewing corporations have to look for new areas which might represent growth in terms of sales and profit. There are new, emerging markets of Asia, South America and Eastern Europe, where consumption and popularity of beer consumption are still growing. There is no doubt that new acquisitions will be seen in a next few years, particularly in these regions.

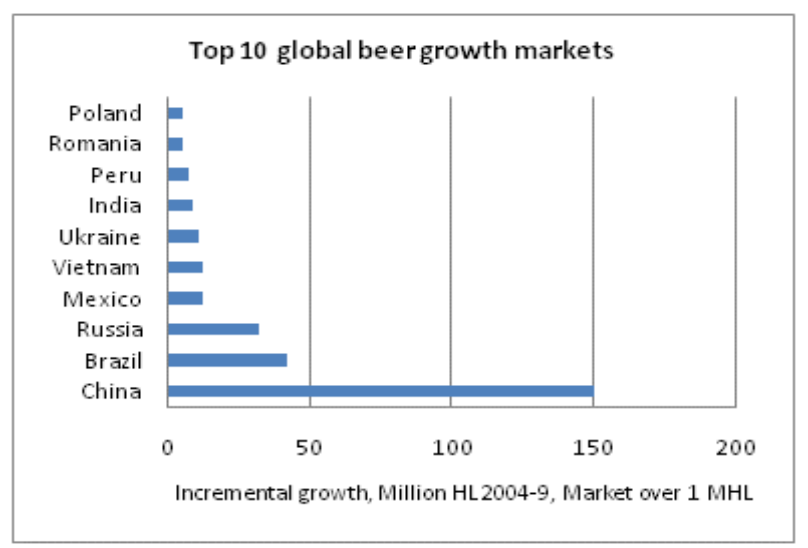

Graph 3. Top 10 global beer growth markets,

\section{DIVERSIFIED BUSINESS STRATEGIES APPROACHES BY TOP GLOBAL PLAYERS}

All global companies have something in common. They try to gain the most of international markets from quantitative (hectolitres sold) or value share (net producer 's revenue) perspective. However their business strategies differ. On the 
one hand, some companies are acquiring local breweries and they implement licence brew of their own international brands (such as Heineken or Carlsberg). On the other hand, a different business strategy is seen from SABMiller or ABInbev. First, they acquire the market leader with its own brand and secure local platform mainly in a mainstream segment and then, they establish the brand in a premium or superpremium segment. Particularly SABMiller strategy is to be number 1 or 2 at the domestic market with the existing local brand. (SABMiller annual report 2010) The key principal of the first approach is to concentrate all sources for brand communication into one brand worldwide. The second business approach is very pragmatic: simply to build on existing local brand equity, awareness and distribution.

\section{WEAKNESSES OF THE GLOBAL PLAYERS}

The global brewing giants 's business strategies are driven by two key initiatives. The first is to increase the value of shares and the second is to deliver dividends to shareholders. Among key producer indicators there are the growth of international market share and profit. To maximize profit, corporations need to have very effective production and distribution network. Licence brewing provides efficient solution to be close with focus brands to its final customers and consumers. However, being big has certain disadvantages. Corporations are investing into modern production and bottling facilities that have to be highly efficient to meet the high market demand. Effectiveness can cause shrinking of the product range (elimination of SKUs for instance) and its variants. Corporations might require certain minimal purchase quantities, offer a limited range of SKUs, etc.

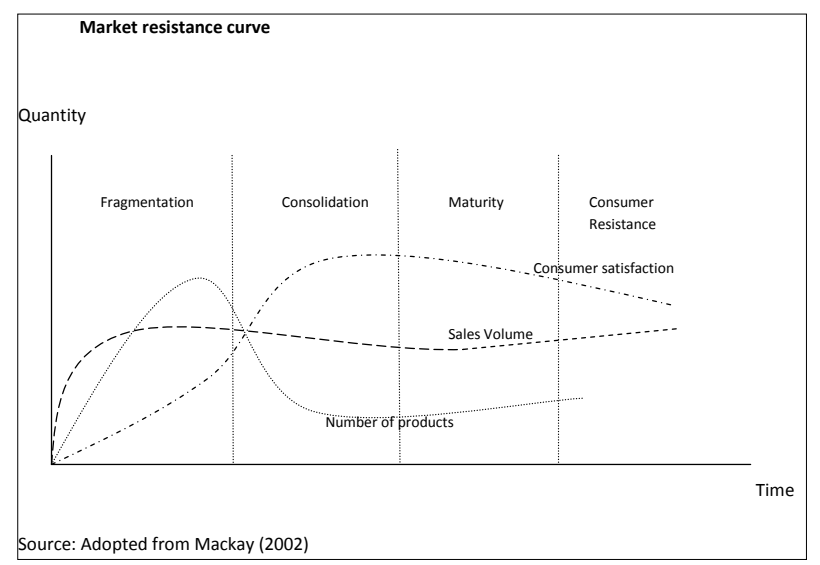

Fig. 1. Market resistance curve

Another threat for larger corporations is the consumer excitement curve, in the final consumers purchasing behaviour. In the initial stage, the consumers are excited by the advertisement, when the beers offered are considered very attractive to target consumers. Nevertheless, from the longer perspective the consumers might find inspirational to experiment with other beers variants or brands. After the initial excitement, particularly in undeveloped markets, consumers might become resistant to heavy advertisement of the highly supported beer brands and search for an alternative in quality as well as taste.

\section{CRAFT (INDEPENDENT) BREWING RENAISSANCE}

In the "developed markets", where the top brewing corporations are already well set up, we can see a trend of matured consumers searching for alternatives that leads to increasing initiatives of independent, small brewers whose popularity and even market/value share is growing dramatically.

For instance, in the USA independent brewers increased their market share to $4,9 \%$ in volume and/or $7,6 \%$ in value, even in a situation of total beer market decline, i. e. $2,2 \%$ in 2010 compare to 2009. (Craft brewing statistics 2010) According to the report, the main reason of such success is the innovative approach, focus on quality and offering wide range of flavours and packaging variants by small brewers. A number of brewers is continuously growing as well.

\section{Total U.S. Breweries}

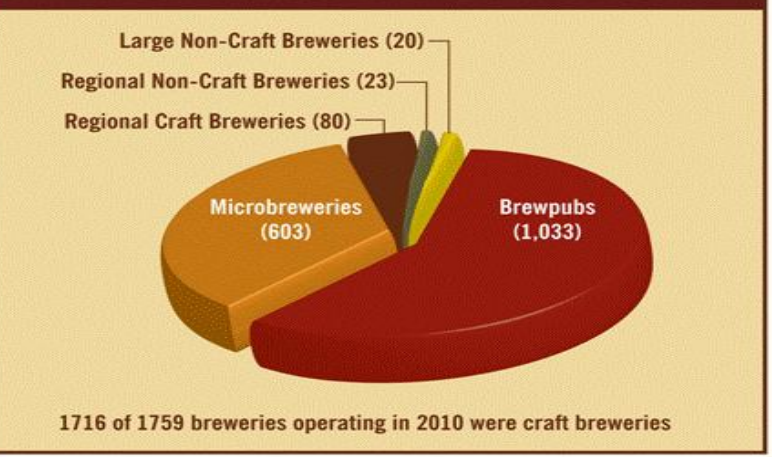

Graph 4. 2010 Total U.S. Breweries, Brewers Association

\section{CONCLUSION}

In forthcoming seasons the beer industry will experience other merges of global beer companies but there is no doubt that the local brewers, who survived the critical period of the second half of twenties century, have chance to provide an alternative offer to local and even to export consumers segments. Experimenting with a wide range of tastes, types and packaging, will be highly beneficial. Beer expertise and ultimate quality experience provided to target consumers will bear fruits in a form of markets shares expansion. Further more, small breweries shall take advantage of very selective tailor made solutions and precise PR campaigns. Local brewers shall maintain its pricing in the niche quality segments carefully and avoid being affected by price war which the biggest brewers are taking part in. Also building a close relationship with communities via effective social responsibility efforts might compete with the heavy corporate initiatives of big corporations, sometimes illegible to the society.

Size of work does not allow deeper analysis of the beer companies business strategies and it focuses only on some facts and implications.

\section{REFERENCES}

*** (2010) http://www.canadean.com/Products/Wisdom_Datab ase/Key_Data_Charts.aspx Accessed on: 2011-08-30

http://www.platologic.co.uk/products.htm Accessed on: 201108-29

*** (2011) http://euromonitor.typepad.com/.a/6a01310f54565d 970c0153905fe9a6970b-popup Accessed on: 2011-08-29

*** (2010) http://www.sabmiller.com/files/reports/ar2010/2010 _annual_report.pdf Accessed on: 2011-08-10

*** (2010) http://www.annualreport.heineken.com/ Accessed on: 2011-08-15

*** (2011) http://www.ab-

inbev.com/go/media/annual_report_2010.cfm Accessed on: 2011-08-15

*** (2011) http://www.brewersassociation.org/pages/businesstools/craft-brewing-statistics/number-of-breweries Accessed on: 2011-08-17 